\title{
VISCERAL METABOLISM AND EFFICIENCY OF ENERGY USE BY RUMINANTS
}

\author{
METABOLISMO VISCERAL E EFICIÊNCIA DO USO DA ENERGIA \\ PELOS RUMINANTES
}

\author{
Gilberto Vilmar Kozloski ${ }^{1}$ João Batista Teixeira da Rocha ${ }^{2}$ \\ Maria de Lourdes Santorio Ciocca ${ }^{3}$
}

\section{- REVIEW -}

\section{SUMMARY}

The visceral system (liver and portal-drained viscera) represents an interface between diet and the animal, and it acts as the main site of regulation of nutrients that are used for maintenance, growth, lactation, reproduction, and physical activities of animals. However the functions carried out by visceral organs have, however, a significant energetic cost and are influenced by a variety of factors, such as the level of feed intake and diet composition, among others. As a result, variable quantities of substances are metabolized by them and, thus, the pattern and the quantity of nutrients available to the peripheral tissues can be quite different from those absorbed at the intestinal lumen. Probably, the major source of variation in the efficiency of utilization of metabolizable energy among feeds is associated mainly with visceral metabolism and it is unlikely that the ratio ketogenic/glucogenic of absorbed substances has determinant effect under physiological conditions.

Key words: portal- drained viscera, liver, metabolism, energy, efficiency.

\section{RESUMO}

O sistema visceral (fígado e vísceras drenadas pela veia porta) representa uma interface entre a dieta e o animal e atua como o principal local de regulação dos nutrientes utilizados para a manutenção, crescimento, lactação, reprodução e atividades físicas dos animais. Contudo, as funções desenvolvidas

\begin{abstract}
por estes órgãos têm um custo energético significativo e são influenciadas por uma série de fatores, como o nível de consumo de alimento e a composição da dieta, entre outros. Como resultado, uma quantidade variável de substâncias são metabolizadas por eles e, deste modo, o padrão e a quantidade de nutrientes disponível aos tecidos periféricos pode ser amplamente diferente daquele absorvido do lúmen intestinal. Provavelmente a maior parte da variação na eficiência de utilização da energia metabolizável entre os alimentos está associada com o metabolismo visceral e é improvável que a relação entre as substâncias cetogênicas/glicogênicas absorvidas tenha um efeito determinante em condições fisiológicas.
\end{abstract}

Palavras-chave: vísceras drenadas pela veia porta, fígado, metabolismo, energia, eficiência.

\section{INTRODUCTION}

Digestion and absorption are the early steps of a complex process through which animals obtain from the environment energetic and constitutive components needed to maintain their living state. In subsequent steps absorbed nutrients enter the bloodstream and are transported to the liver by the portal venous system. Together with

\footnotetext{
${ }^{1}$ Student of Animal Husbandry, Universidade Federal do Rio Grande do Sul (UFRGS). Departamento de Química, Universidade Federal de Santa Maria (UFSM), Campus Camobi, 97105-900, Santa Maria, RS, Brasil. Email: kozloski@mousenet.com.br. To whom correspondence should be addressed.

${ }^{2}$ Professor, Departamento de Química, UFSM.

${ }^{3}$ Professor, Departamento de Zootecnia, UFRGS. 
exogenous nutrients, endogenous circulating metabolites derived from peripheral tissues also reaches the liver. As a part of this system, the liver can be regarded as a central regulator that controls the levels of nutrients that will be distributed to the body and ensure the maintenance, growth, lactation, reproduction, and all the physical activities of animals (SEAL \& REYNOLDS, 1993).

The functional role played by visceral tissues (liver and portal-drained viscera (PDV)) has a considerable energetic cost and a variable quantity of substrates are metabolized by them (HUNTINGTON \& REYNOLDS, 1987). Thus, changes in the metabolism of visceral tissues can change the proportions and the absolute quantities of metabolites that become available to the peripheral tissues and consequently can influence the metabolism of the whole organism.

Critical considerations about techniques used on studies dealing with visceral metabolism and on visceral metabolism of important nutrients have been considered in previous reviews (SEAL \& REYNOLDS (1993), REYNOLDS (1995) and HUNTINGTON (1999)). The objective of the present review is to consider some factors that associate the visceral metabolism with the energetic efficiency of the whole organism of ruminant.

\section{VISCERAL FLUX OF ENERGY}

The portal energy flux is the sum of enthalpy of combustion of metabolites absorbed plus the visceral heat production estimated from oxygen consumed by the system. It represents up to $92 \%$ of the metabolizable energy (ME) intake (LINDSAY, 1993). The net portal energy flux would be expected to account to $100 \%$ or more of the ME intake. The difference between obtained and expected values has been associated with metabolites not determined in blood samples, such as nitrogen bases, peptides, and phenols, with fermentation heat and metabolites absorbed through the lymph, such as lipids. The portal flux of volatile fatty acids (VFA) is linearly correlated and represent about $43 \%$ of ME intake (Figure 1). The others significant components of portal flux of energy are oxygen uptaked, amino acids, ketone bodies, and lactate.

REYNOLDS (1995), in a review of several studies carried out on cattle, observed that the energy released by the total visceral system in the form of metabolizable compounds corresponds to about $87 \%$ of ME intake. Visceral acetate release

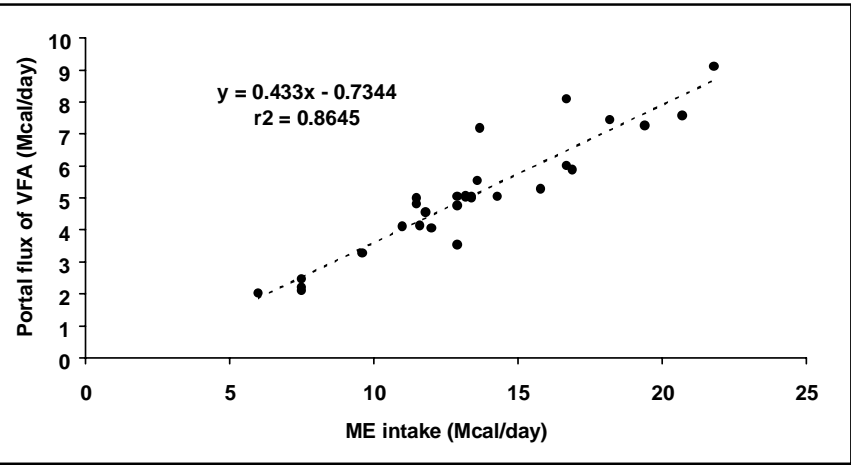

Figure 1 - Relation between ME intake and net portal flux of energy as volatile fatty acids (VFA: acetate + propionate + butyrate). Data were taken from experiments with steers and heifers conducted by HUNTINGTON \& PRIOR (1983), HARMON \& AVERY (1987), HARMON et al. (1988), GROSS et al. (1988), REYNOLDS \& HUNTINGTON (1988), THEURER $\boldsymbol{e t}$ al. (1991), KREHBIEL et al. (1992), SEAL et al. (1992), SEAL \& PARKER (1994), TANIGUCHI et al. (1995) and HUNTINGTON et al. (1996). The combustion heat used to calculate the energy of VFA was 209,365 and $552 \mathrm{kcal} / \mathrm{mol}$ of acetate, propionate and butirate, respectively.

normally represents about $24 \%, \beta-\mathrm{OH}$-butyrate $16 \%$, glucose $23 \%$, and amino acids $5 \%$ of the ME intake .

The forage:concentrate ratio in the diet or the site of starch digestion does not seem to change the total quantity of energy released by the visceral system for a fixed level of ME intake. However, the metabolizable components of this energy are different. A higher proportion of net visceral energy flux is represented by acetate on forage-based diets or when starch is fermented into the rumen, but on concentrate-based diets or when starch digestion ocurr in the small intestine, a higher proportion is represented by glucose (TANIGUCHI et al., 1995; HUNTINGTON et al., 1996).

The site of protein digestion affected neither the quantity of net visceral energy flux nor the proportion of metabolites components of this energy (TANIGUCHI et al., 1995). However, the increase of protein intake decreased the net visceral energy release in the form of aminoacids by steers (REYNOLDS et al., 1992).

\section{ENERGY CONSUMPTION BY VISCERAL SYSTEM}

The visceral metabolism alters the pattern and the amount of available nutrients to the peripheral tissues but also spends a significant part of energy consumed by the whole organism. The increase of feed or energy intake increases both the mass of these organs in relation to total body mass (BURRIN et al., 1990) and the 
metabolic activity of these tissues (REYNOLDS, 1995).

Data

compilated

by

HUNTINGTON (1999), from experiments with cattle and sheep fed up to about two times their energy maintenance requirement, demonstrated that the oxygen uptake by visceral tissues is linearly related to whole body oxygen uptake (about 40\%). However, GOETSCH (1998) analysed data from experiments with sheeps fed forage-based diets ad libitum and observed that the efficiency of energy metabolism of visceral tissues increased as the level of ad libitum intake increased, i.e., the oxygen uptake by visceral tissues decreased when compared to whole body oxygen uptake. Similarly, portal and liver aerobic heat production (estimated from oxygen uptake) in cattle were linearly related to ME intake (SEAL \& REYNOLDS, 1993, REYNOLDS, 1995). Thus, considering that the efficiency of utilization of ME by the whole body decreases as the level of ME intake increases, i.e., the whole body heat production increases in relation to ME intake (KETELAARS \& TOLKAMP, 1996), it also indicates that the efficiency of energy metabolism of visceral tissues increases as level of ME intake increases. The difference between the above studies (HUNTINGTON, 1999 vs. SEAL \& REYNOLDS, 1993, REYNOLDS, 1995, GOETSCH, 1998) about oxygen consumption and energetic efficiency of visceral system can be related to difference on level of fed intake of experimental animals. REYNOLDS et al. (1994) observed a biphasic response in the portal-drained viscera of cattle, where the increase in portal heat production with increasing metabolizable energy intake appears to be reduced at intakes greater than twice maintenance.

The forage: concentrate ratio of the diet can affect the energy expenditure by the visceral system. REYNOLDS et al. (1991) fed heifers with pelleted diets containing $75 \%$ alfalfa or $75 \%$ concentrate, at equal ME intake and at two levels of intake. Some results of this study are summarized in table 1 . They observed a greater production of heat by the whole body and a lower retention of tissue energy for the diet containing more forage, which resulted from differences in visceral tissues metabolism, mainly the PDV.

The characteristics of forage is another factor that may affect visceral energy consumption. In studies with sheep, the visceral energy consumption in relation to digestible energy intake
Table 1 - Intake of ME and oxygen uptake by tissues of heifers fed $75 \%$ alfafa or $75 \%$ concentrate diet at two levels of intake (REYNOLDS et al., 1991) ${ }^{1}$.

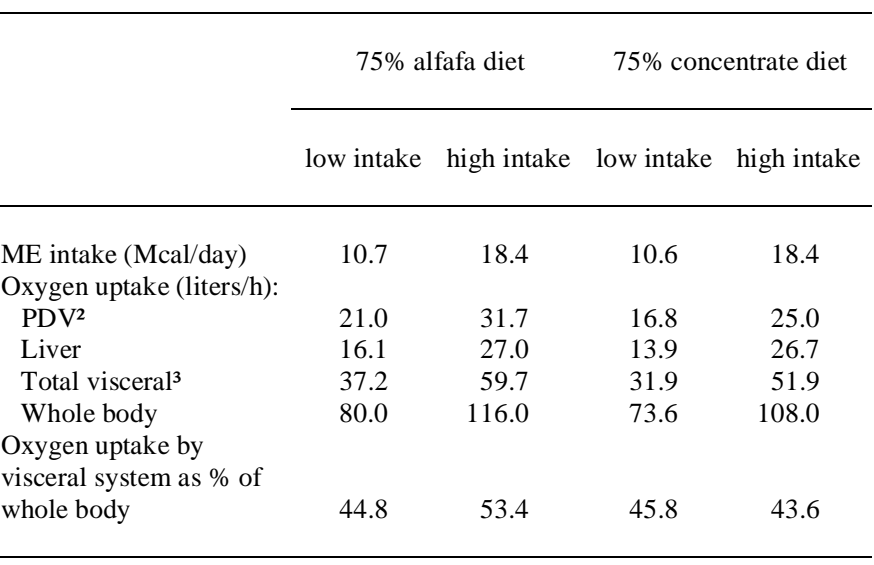

${ }^{1}$ Heifers were multicatheterized for visceral measurements and were placed in respiratory chambers for measurements of whole body energy and nitrogen balance.

Probability of diet effect: $\mathrm{P}<0.01$

Probability of diet effect: $\mathrm{P}<0.07$

was higher to bermudagrass than ryegrass-wheat hay (GOETSCH \& FERRELL,1995; PATIL et al., 1995; GOETSCH et al., 1997). The time of intake and digesta mass in sheep fed bermudagrass (a more fibrous forage) is higher compared to ryegrass-wheat hay (SUN et al., 1994). A larger digesta mass may cause a greater energy consumption due to a higher metabolic activity of epithelial cells and to a higher contractile activity of muscle cells in the digestive tract. In addition, although the mecanisms are unknown, there is a high flow of sodium ions in the saliva when animals receive high fiber diets, which have been suggested to increase energy use by the gut (KETELAARS \& TOLKAMP, 1996).

Increased crude protein intake increased oxygen consumption by the portal system and by the liver in steer (REYNOLDS et al., 1992) and sheep (GREANEY et al., 1996). In addition, infusions into the mesenteric vein of an amino acid mixture stimulated oxygen uptake by these organs in sheep (LOBLEY et al., 1998). In these studies, the increased uptake of oxygen by the liver was associated with urea synthesis. Indeed, there is a significant correlation $\left(r^{2}=0.70\right)$ between oxygen uptake and urea $\mathrm{N}$ production by liver when data from various experiments with steers are compared (Figure 2). However, ammonia infusion into the mesenteric vein of sheep (LOBLEY et al., 1995) or amino acid infusion into the mesenteric vein of dry dairy cows (WRAY-CAHEN $\boldsymbol{e t}$ al., 1997) increased hepatic urea synthesis but had no effect on oxygen 


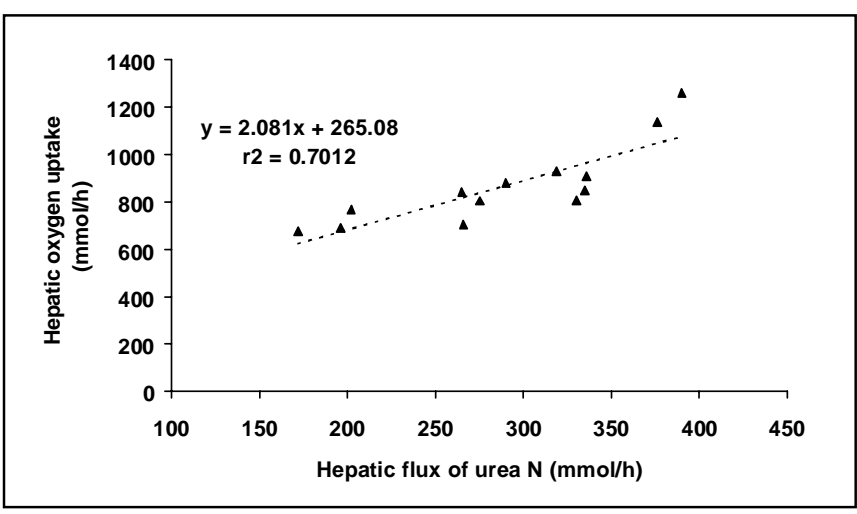

Figure 2 - Relation between hepatic production of urea $\mathrm{N}$ and hepatic oxygen uptake. Data were taken from experiments with steers conducted by GUERINO et al. (1991), REYNOLDS $\boldsymbol{e t}$ al. (1992), BAUER et al. (1995) and T ANIGUCHI et al. (1995).

uptake by visceral system. Urea synthesis had a cost estimated from 1 to $4 \mathrm{~mol}$ of ATP for mol of urea (LEHNINGER et al., 1993), depending on whether fumarate production in the urea cycle is considered in energetic calculations or not. However, as more amino acids are deaminated to support the increase in urea synthesis, more gluconeogenic substrates will be available in the hepatocytes. The main amino acids used as precursors of glucose in ruminant liver, in fed state, are alanine and glycine (REYNOLDS, 1995) enter into the gluconeogenic pathway as pyruvate (LEHNINGER et al., 1993). The glucose synthesis from these substrates had an estimated cost of 12 mol of ATP for mol of glucose synthetized (LEHNINGER $\boldsymbol{e t}$ al., 1993) and, thus, it is certainly associated with a significant increase of ATP consumption by the hepatocytes when protein-rich diets are fed.

The energy expenditure by the visceral system is also affected by the site of starch digestion. TANIGUCHI $\boldsymbol{e}$ t al. (1995) infused starch into the rumen or abomasum of steers fed alfalfa hay and observed that the oxygen uptake by the portal system and the liver was higher in the animals that received infusion into the abomasum. However, the net visceral flux of energy, as metabolizable nutrients for use by peripheral tissues, was also higher in this treatment compared with starch infusion into the rumen. Thus, the net availability of energy for use by peripheral tissues, as a proportion of energy intake, was similar to corn starch digested in the rumen or in the lower gastrointestinal tract of steers. Although there is a loss of starch energy when it is fermented in the rumen, giving origin to VFA, this loss is counterbalanced by the energy consumed in the small intestine to absorb glucose when starch is digested by the enzymes of ruminants at this site (McBRIDE \& KELLY, 1990).

\section{VISCERAL METABOLISM AND WHOLE ENERGY EFFICIENCY}

The differences on efficiency of ME use by ruminants have generally been attributed to ketogenic/glycogenic ratio of digestion and absorption products (ØRSKOV, 1977; REYNOLDS, 1995). However, in studies on sheep (ØRSKOV et al., 1979) and steers (ØRSKOV et al., 1991), no significant differences were detected on nitrogen retention or on the efficiency of energy utilization from different VFA mixtures infused into the rumen, above the maintenance level. Moreover, in studies "in vitro" with ovine adipocytes, the variation in glucose concentration within the physiological range ( 2 to $5 \mathrm{mM}$ ) in the incubation media had no effect on acetate metabolism. In addition, acetate oxidation and conversion to lipid increased with acetate concentrations in the media, also within the physiological range $(0.5$ to $1.5 \mathrm{mM})$, even though glucose concentrations were low (YANG \& BALDWIN, 1973; SCOLLAN \& JESSOP, 1995). Yet, in these studies, the lack of glucose oxidation limited acetate incorporation into lipid but only at concentrations of acetate above physiological range. Another important aspect to be considered, is that visceral metabolism greatly modifies the pattern and quantity of available nutrients to peripheral tissues in relation to those that disappear from the intestinal lumen. Thus, even in the most different dietary conditions, the ratio of the ketogenic/glucogenic substrates (on an energetic basis) released by the visceral system to peripheral tissues is about two times (REYNOLDS, 1995), which is unlikely to limit acetate utilization. Indeed, differences in efficiency of utilization of ME among feeds are likely to be associated with metabolism of visceral tissues and not with metabolism of peripheral tissues. REYNOLDS et al. (1991) observed in steers that most of the increase in heat generated by increasing intake of a roughage-based-diet was aerobically generated in the visceral system and not in peripheral tissues. In addition, SUSENBETH $\boldsymbol{e t}$ al. (1998) verified that the energy requirement for eating and ruminating is high and different among feeds. When untreated straw was fed to steers, approximately $30 \%$ of ME provided by the feed was used to supply energy demanded for eating and 
ruminating. In turn, when a high-quality roughage was fed, only $10 \%$ of ME was used for these physiological functions.

In the other hand, LENG (1990) observed that supplementation of roughage-based-diets with urea and protein sources of low degradability, greatly increased the efficiency in the utilization of the ME provided by roughage and that this would be due to a higher utilization of acetate for synthetic processes and to a decrease in the production of futile heat by the ruminant. Indeed, SCOLLAN \& JESSOP (1995) verified a higher incorporation of acetate into lipid on adipocytes of sheep fed diets containing high protein compared with low protein content. However, alternatively to that stated by LENG (1990), it is possible that higher aminoacids supply led to a higher glucose production from gluconeogenic aminoacids by the liver. Thus, the increased glucose supply could have a sparing effect on acetate oxidation by the peripheral tissues, increasing its incorporation into lipid (BALCELLS et al., 1995). In addition, a higher aminoacids supply can lead to low oxidation of aminoacids present into the cells of peripheral tissues. Consequently, the protein renewal in these tissues decreases and the deposited/synthesised protein ratio increases, lowering ATP expenditure by protein turnover (ABDUL-RAZZAQ \& BICKERSTAFFE, 1989). KREHBIEL et al. (1998) supplemented ewes fed low-quality forage "ad libitum" with soybean meal and observed that this supplementation increased the net portal flux of $\alpha$-amino nitrogen but did not increase the total net visceral flux. The additional aminoacids flux from portal blood in these supplemented ewes was uptaken by the liver and did not reach peripheral tissues. Moreover, the hepatic uptake of lactate, mainly of peripheral origin, was higher in no supplemented ewes, suggesting a change of glucose precursors from lactate in no supplemented to aminoacids in supplemented ewes.

\section{CONCLUSIONS}

The portal-drained viscera and the liver metabolism have a profound impact on the availability of nutrients and energy to the peripheral tissues, which is influenced by several factors, such as level of feed intake and diet composition. Probably, the major source of variation in the efficiency of utilizing metabolizable energy among feeds is associated mainly with visceral metabolism and it is unlikely that the ratio ketogenic/glucogenic of absorbed substances has determinant effect under physiological conditions. However, excepting few experiments with sheep fed forage "ad libitum", these conclusions are obtained, for the most part, from results of experiments with sheep and growing cattle fed near or slightly above maintenance levels. There are few data and, thus, more research is necessary to describe visceral metabolism of high yielding dairy cow and of ruminants with high levels of intake.

\section{REFERENCES}

ABDUL-RAZZAQ, H.A., BICKERSTAFFE, R. The influence of rumen volatile fatty acids on protein metabolism in growing lambs. British Journal of Nutrition, v.62, p.297-310, 1989.

BALCELlS, J., SEAL, C.J., PARKER, D.S. Effect of intravenous glucose infusion on metabolism of portal-drained viscera in sheep fed a cereal/straw-based diet. Journal of Animal Science, v.73, p.2146-2155, 1995.

BAUER, M.L., HARMON, D.L., McLEOD, K.R., $\boldsymbol{e}$ t al. Adaptation to small intestinal starch assimilation and glucose transport in ruminants. Journal of Animal Science, v.73, p.1828-1838, 1995.

BURRIN, D.G., FERREL, C.L., BRITTON, R.A., et al. Level of nutrition and visceral organ size and metabolic activity in sheep. British Journal of Nutrition, v.64, p.439-448, 1990.

GOETSCH, A.L. Splanchnic tissue energy use in ruminants that consume forage-based diets ad libitum. Journal of Animal Science, v.76, p.2737-2746, 1998.

GOETSCH, A.L., FERREL, C.L. Effects of dietary maize level on net flux across splanchnic tissues of oxigen and nutrients in wethers consuming ad libitum different forages. Animal Science, v.61, p.43-55, 1995.

GOETSCH, A.L., PATIL, A.R., GALlOWAY, D. L., et al. Net flux of nutrients across splanchnic tissues in wethers consuming grasses of different sources and physical forms ad libitum. British Journal of Nutrition, v.77, p.769-781, 1997.

GROSS, K.L., HARMON, D.L., AVERY, T.B. Net portal nutrient flux in steers fed diets containing wheat and sorghum grain alone or in combination. Journal of Animal Science, v.66, p.543-551, 1988.

GREANEY, K. B., REYNOLDS, G. W., ULYATT, M. J., et al. The metabolic cost of hepatic ammonia detoxification. Proceedings of New Zealand Society of Animal Production, v.56, p.130-132, 1996.

GUERINO, F., HUNTINGTON, G.B., ERDMAN, R.A. The net portal and hepatic flux of metabolites and oxigen consumption in growing beef steers given postruminal casein. Journal of Animal Science, v.69, p.387-395, 1991.

HARMON, D.L., AVERY, T.B. Effects of dietary monensin and sodium propionate on net nutrient flux in steers fed a highconcentrate diet. Journal of Animal Science, v.65, p.1610-1616, 1987.

Ciência Rural, v. 31, n. 5, 2001. 
HARMON, D.L., AVERY, T.B., HUNTINGTON, G.B., et $\boldsymbol{a}$. Influence of ionophore addition to roughage and high concentrate diets on portal blood flow and net nutrient flux in cattle. Canadian Journal of Animal Science, v.68, p.419429, 1988.

HUNTINGTON, G.B. Nutrient metabolism by gastrointestinal tissues of herbivores. In: JUNG, H.G., FAHEY JR., G.C. (Eds.) Nutritional ecology of herbivores. Savoy : ASAC, 1999. p.312-335.

HUNTINGTON, G.B., PRIOR, R.L. Digestion and absorption of nutrients by beef heifers fed a high concentrate diets. Journal of Nutrition, v.113, p.2280-2288, 1983

HUNTINGTON, G.B., REYNOLDS, C.K. Oxygen consumption and metabolite flux of bovine portal-drained viscera and liver. Journal of Nutrition, v.117, p.1167-1173, 1987

HUNTINGTON, G.B., ZETINA, E.J., WHITT, J.M., et al. Effects of dietary concentrate level on nutrient absorption, liver metabolism, and urea kinetics of beef steers fed isonitrogenous and isoenergetic diets. Journal of Animal Science, v.74, p.908-916, 1996

KETELAARS, J.J.M.H., TOLKAMP, B.J. Oxygen efficiency and the control of energy flow in animals and humans. Journal of Animal Science, v.74, p.3036-3051, 1996.

KREHBIEL, C.R., HARMON, D.L., SCHNEIDER, J.E. Effect of increasing ruminal butyrate on portal and hepatic flux in steers. Journal of Animal Science, v.70, p.904-914, 1992.

KREHBIEL, C.R., FERREL, C.L., FREETLY, H.C. Effects of frequency of supplementation on dry matter intake and net portal and hepatic flux of nutrients in mature ewes that consume low-quality forage. Journal of Animal Science, v.76, p.2464 -2473, 1998.

LENG, R.A. Factors affecting the utilization of 'poor-quality' forages by ruminants particulary under tropical conditions. Nutrition Research Review, v.3, p.277-303, 1990.

LEHNINGER, A.L., NELSON, D.L., COX, M.M. Principles of biochemistry. 2.ed. New York : Worth Publishers, 1993. $1013 \mathrm{p}$.

LINDSAY, D.B. Metabolism of the portal-drained viscera. In FORBES, J.M., FRANCE, J. (Eds.) Quantitative aspects of ruminant digestion and metabolism. Wallingford : $\mathrm{CAB}$ International, 1993. p.267-290.

LOBLEY, G.E., CONNEL, A., LOMAX, M.A., et al. Hepatic detoxification of ammonia in the ovine liver. British Journal of Nutrition, v.73, p.667-685, 1995.

LOBLEY, G.E., BREMNER, R.N., OBITSU, T., et al. Transfers of $\mathrm{N}$ metabolites across the ovine liver in response to shortterm infusions of an amino acid mixture into the mesenteric vein. British Journal of Nutrition, v.80, p.371-379, 1998.

MCBRIDE, B.W., KELLY, J.M. Energy cost of absorption and metabolism in the ruminant portal-drained viscera and liver: a review. Journal of Animal Science, v.68, p.2997-3010, 1990.
ØRSKOV, E.R. Capacity for digestion and effects of composition of absorbed nutrients on animal metabolism. Journal of Animal Science, v.46, p.600-608, 1977.

ØRSKOV, E.R., GRUBB, D.A., SMITH, J.S., et al. Efficiency of utilization of volatile fatty acids for maintenance and energy retention by sheep. British Journal of Nutrition, v.41, p.541-551, 1979.

ØRSKOV, E.R., MACLEOD, N.A., NAKASHIMA, Y. Effect of different volatile fatty acids mixtures on energy metabolism in cattle. Journal of Animal Science, v.69, p.3389-3397, 1991.

PATIL, A.R., GOETSCH, A.L., GALlOWAY, D.L., et al. Net flux of nutrients across splanchnic tissues in sheep consuming ad libitum different proportions of bermudadrass and ryegrass-wheat hay. Journal of Animal Science, v.73, Suppl.1, p.261, 1995. (Abstracts).

REYNOLDS, C.K. Quantitative aspects of liver metabolism in ruminants. In: VON ENGELHARDT,W., LEONHARDMAREK, S., BREVES, G, et al. (Eds) Ruminant physiology: digestion, metabolism, growth and reproduction. Sttutgart : Ferdinand Enke Verlag, 1995. p.351-371.

REYNOLDS, C.K., HUNTINGTON, G.B. Partition of portaldrained visceral net flux in beef steers. 2 . Net flux of volatile fatty acids, D- $\beta$-hydroxybutirate and L-lactate across stomach and post-stomach tissues. British Journal of Nutrition, v.60, p.553-562, 1988.

REYNOLDS, C.K., TYRREL, H.F., REYNOLDS, P.J. Effects of diet forage-to-concentrate ratio and intake on energy metabolism in growing beef heifers: Whole body energy and nitrogen balance and visceral heat production. Journal of Nutrition, v.121, p.994-1003, 1991.

REYNOLDS, C.K., CASPER, D.P., HARMON, D.L., et al. Effect of $\mathrm{CP}$ and ME intake on visceral nutrient metabolism in beef steers. Journal of Animal Science, v.70, Suppl. 1, p.315, 1992. (Abstracts).

REYNOLDS, C.K., HARMON, D.L., CECAVA, M.J. Absorption and delivery of nutrients for milk protein synthesis by portal-drained viscera. Journal of Dairy Science, v.77, p.2787 -2808, 1994.

SCOLLAN, N.D., JESSOP, N.S. Diet-induced variation in acetate metabolism of ovine perirenal adipose tissue in vitro. Journal of Agricultural Science, v.125, p.429-436, 1995.

SEAL, C.J., REYNOLDS, C.K. Nutritional implications of gastrointestinal and liver metabolism in ruminants. Nutrition Research Review, v.6, p.185-208, 1993.

SEAL, C.J., PARKER, D.S. Effect of intraruminal propionic acid infusion on metabolism of mesenteric - and portal-drained viscera in growing steers fed a forage diet: I. Volatile fatty acids, glucose, and lactate. Journal of Animal Science, v.72, p.1325-1334, 1994 
SEAL, C.J., PARKER, D.S., AVERY, P.J. The effect of forageconcentrate diets on rumen fermentation and metabolism of nutrients by the mesenteric- and portal-drained viscera in growing steers. British Journal of Nutrition, v.67, p.355370,1992

SUN, W., GOETSCH, A.L., FORSTER JR., L.A. et al. Forage and splanchnic tissue mass in growing lambs: effects of dietary forage levels and source on splanchnic tissue mass in growing lambs. British Journal of Nutrition, v.71, p.141$151,1994$.

SUSENBETH, A., MAYER, R., KOEHLER, B., et al. Energy requirement for eating in cattle. Journal of Animal Science v.76, p.2701-2705, 1998

TANIGUCHI, K., HUNTINGTON, G.B., GLENN, B.P. Net nutrient flux by visceral tissues of beef steers given abomasal and ruminal infusions of casein and starch. Journal of Animal Science, v.73, p.236-249, 1995

THEURER, C.B., HUNTINGTON, G.B., SWINGLE, R.S., et al Net VFA and energy absorption in beef steers fed diets containing $77 \%$ dry-rolled (DR) or steam-flaked (SF) sorghum grain. Journal of Animal Science, v.69, Suppl.1, p.503-504, 1991. (Abstracts).

WRAY-CAHEN, D., METCALF, J.A., BACKWELL, F.R.C. $\boldsymbol{e}$ al. Hepatic response to increased exogenous supply of plasma amino acids by infusion into the mesenteric vein of Holstein-Friesan cows in late gestation. British Journal of Nutrition, v.78, p.913-930, 1997.

YANG, Y.T., BALDWIN, R.L. Preparation and metabolism of isolated cells from bovine adiposo tissue. Journal of Dairy Science, v.56, p.350-365, 1973.

Ciência Rural, v. 31, n. 5, 2001. 